\title{
PROSES MANAJEMEN PERKANTORAN DI BADAN PUSAT STATISTIK (BPS) KABUPATEN PIDIE
}

\author{
Armiwal \\ Program Studi Ilmu Sosial Politik Fakultas Sosial Politik \\ Universitas Iskandarmuda \\ Banda Aceh
}

\begin{abstract}
Every organization that is formed, is cooperation between several people who have a purpose. In the process of achieving that goal many factors are determining, the only regular management factor, the success or failure of an organization or institution is determined from the orderly administration and management and the person who leads the organization concerned. It is clear that a good management arrangement as well as a regular administration will determine the success of a business in every management process to achieve a specific purpose.In order to increase the efficiency and effectiveness of the implementation of office management, it is necessary to implement various office activities based on a system so that the desired goals will reach the target. The tasks assigned to each section must be refused to prevent abuse or overlap in the performance of the task. The skills of an employee is very supportive to the process of office management in an organization, because without a skilled employee it is unlikely to be able to support work activities and can not also improve the ability of work so that the need for guidance on employees continuously. In terms of coaching the employees of the Central Bureau of Statistics (BPS) of Pidie Regency.To overcome this problem, the government has tried to pursue various ways, either by training or upgrading in a staffing field or by creating new, more efficient and effective methods in order to improve the management and administration process by completing the tools that are carried out continuously. However, the fact of office management process in Central Bureau of Statistics (BPS) of Pidie Regency is still in medium category.
\end{abstract}

Keywords: Office Management.

\section{PENDAHULUAN}

Setiap kegiatan dalam suatu
organisasi baik organisasi Pemerintahan maupun organisasi swasta memerlukan adanya manajemen yang teratur. Hal ini disebabkan berhasil tidaknya dari sebuah organisasi atau lembaga sangat ditentukan dari tertib administrasi dan manajemen serta orang yang memimpin organisasi yang bersangkutan.

Dalam hal ini dapat diiihat pada Negaranegara yang telah maju mengenaipelaksanaan program kerja mereka pada umumnya telah berhasil merencanakan, menggerakkan, mengkoordinir dan mengintegrasikan serta dapat menyederhanakan berbagai macam keahlian, kegiatan, disiplin ilmu dan perasaan menjadi satu mata rantai yang paling berkaitan antara satu dengan yang lainnya.

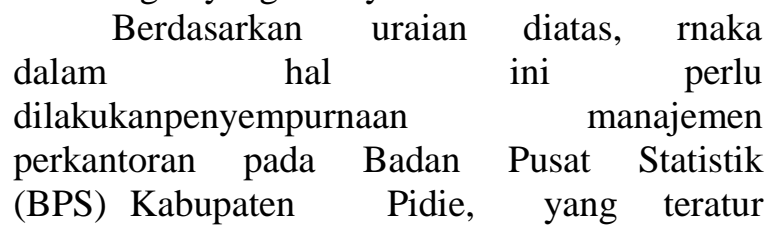

$\begin{array}{lrr}\text { sedemikian rupa agar } & \text { pelayanan } \\ \text { terhadapmasyarakat } & \text { dapat } & \text { terlaksana } \\ \text { sebagaimana } & \text { Proses } \\ \text { manajemenperkantoran } & \text { Badan } & \text { Pusat }\end{array}$ Statistik (BPS) Kabupaten Pidie dilakukan oleh pegawai yang diberi tugas untuk itu. Ada beberapa jenis manajemen perkantoran yang dilaksanakan Badan Pusat Statistik (BPS) Kabupaten Pidie, meliputi manajemen kepegawaian, sarana dan prasarana dan lainlain yang berkenaandengan kegiatan perkantoran atau ketatausahaan.

Keberadaan pegawai sebagai unsur peJaksana tugas yang menyangkut dengan proses manajemen perkantoran Badan Pusat Statistik (BPS) Kabupaten Pidie, diharapkan agar tugas-tugas tersebur dapat diJaksanakan secara berdaya guna, yang pada gilirannya keseluruhan tugas yang ada dapat berjalan sebagaimana yang diharapkan.

Berdasarkan pengamatan yangdilakukan oleh penulis menunjukan bahwa proses manajemen perkantoran BadanPusat Statistik (BPS) Kabupaten Pidie belum dapat 
dilaksanakan

sebagaimana mestinya,

dikarenakan adanya beberapa faktor penghambat dalam pelaksanaannya.

\section{LANDASAN TEORITIS DA TINJAUAN KEPUSTAKAAN}

\section{Proses}

Pengertian proses menurut pendapat yang dikemuk:akan oleh Siodoro (2004: 12) yaitu: "Serangkaian langkah sistematis, atau tahapan yang jelas dan dapat ditempuh berulangkali, untuk mencapai hasil yang diinginkan. Jika ditempuh, setiap tahapan itu secara konsisten mengarah pada hasil yangdiinginkan".

Pendapat lain dikemukakan oleh lrra Chrisyanti Dewi (2000: 8) Prosesadalah : "Urutan pelaksanaan atau kejadian yang terjadi secara alami atau didesain, mungkin menggunakan waktu, ruang, keahlian atau sumber daya lainnya, yang menghasilkan suatu hasil".

Kemudian Sukoco (2007 : 22) Proses adalah : "Serangkaian kegiatan yang saling terkait atau berinteraksi, yang mengubah input menjadi output Kegiatan ini memerlukan alokasi sumber daya seperti orang dan materi. Input dan output yang dimaksudkan mungkin tangible (seperti peralatan, bahan atau komponen) atau tidak berwujud (seperti energi atau infonnasi)".

Manajemen sebagai proses merupakan keseluruhan usaha atau kegiatan mengelola sumber daya atau sarana berupa pegawai, uang,peralatan, metode kerja dan lain-lain dengan baik. Proses manajemen kantor dalam pelaksanaan kegiatannya sangat dominan melakukan aktifitas pada setiap bidang manajemen lainya, pelaksanaan segenap kegiatan pelaksanaan manajemen tersebut sangat tampak sisi positif dan terakumulasi pada pelaksanaan bidang manajemen kantor yang dapat dilihat dari sudut proses manajemen itu sendiri.

Bermacam kegiatan personalisa tatausaha yang dilakukan dalam sebuahkantor dibawah bimbingan seoarang manajer yang berdasarkan pengarahan tertentu merupakan pelaksanan kantor yang kerap kali juga disebut "pembimbingan kantor".
Pembimbingan tidak hanya menentukan arah, tetapi juga memotivasijiwa untuk mencapai arah yang benar.

\section{Manajemen}

Definisi manajemen menurut rumusan yang dikemukakan oleh Sarwoto(2000 : 4) yaitu : "Manajemen adalah suatu proses yang tcrdiri dari tindakan-tindakan planning, organizing, actuating, controlling, dinamika pada masing-masing bidang yang dipergunakan, baik ilmu pengetahuan maupun keahliandan diikuti secara berurutan dalam rangka usaha mencapai sasaran yang telah ditetapkan semula.

Sedangkan pengertian manajemen menurut Winardi(2002 : 10) yang menyatakan bahwa manajemen adalah : "Merupakan suatau proses yang khas yang terdiri dari tindakan-tindakan perencanaan, pengarahan, pengorganisasian, menggerakk:an dan pengawasan yang dilakukan untuk: menentukan serta mencapai sasaran-sasaran yang telah ditetapkan melalui pennanfaatan sumbar daya manusia serta sumber-sumber lain."

Pendapat lain tentang manajemen dikemukakan oJeh M. Manullang(2004 : 3) yaitu: "Manajemen sebagai kolektifitas manajemen dalam suatu badan tertentu disebut manajemen, dalam arti singular (tunggal) disebut manajemen. Manajer adalah pejabat yang bertangggungjawab atas terselenggaranya aktifitas manajemen agar tujuan unit yang dipimpinnya tercapai dengan menggunakan bantuan orang lain."

Pendapat lain tentang manajemen juga dikemukakan oleh Sondang P. Siagian (2002: 3) yaitu:"Manajemen adalah keterampilan untuk memperoleh basil dalam rangka pencapaian tujuan yang telah ditenrukan sebelumnya dengan menggerakkan orangorang lain didalam organisasi”.

a. Aktivitas manajemen perkantoran

Aktivitas manajemen kantor sangat luas dan antara berbagai bentuk badan usaha tidak sama. Hal ini dipengaruhi oleh Juasnya tujuan dari masing- masing badan usaha. Semakin luas tujuan yang akan dicapai, semakin luas pula aktivitas manajemen perkantorannya, disamping dipengaruhi oleh faktor luasnya tujuan yang hendak dicapai. Aktivitas manajemen kantor juga dipengaruhi oleh belum adanya suatu keseragaman dan kesepakatan antara para ahli, tentang aktivitas 
apa saja yang harus menjadi fungsi seorang manajer kantor.

Aktivitas pekerjaan kantor pada umumnya terdiri dari aktivitas-aktivitas yang berhubungan dengan.

$>$ Perencanaan perkantoran (Office Planning)

$>$ Pengorganisasian perkantoran (Office Organizing)

$>$ Pengawasan perkantoran (Office Controling)

Sebagairnana telah diuraikan dimuka, bahwa kantor adalah keseluruhan ruang dalam suatu bangunan, di mana dilaksanakan tata usaha atau dilakukan aktivitas-aktivitas manajemen maupun berbagai tugas dinaslainnya.

\section{Tujuan Manajemen Perkantoran}

Dalam proses manajemen, sasaran yang dituju adalah tercapainya rujuan secara efisien. Yang dimaksud efisien disini adaiah memenuhi persyaratan baik ditinjau dari segi ekonomis, teknis, dan psikologis. Ekonomis. Bukan berarti murah dari segi biaya, tetapi pantas dan sesuai.

\section{Kantor}

Pengertian kantor menurut pendapat yang dikemukakan oleh Prajudi Admosudirjo (1998 : 23) yaitu : "Unit organisasi yang terdiri atas tempat, staf personil, operasi ketatausahaan guna membantu pimpinannya".

Lebih lanjut The Liang Gie (2001 : 105 ) mengatakan bahwa "Kantor adalah tempat dalam suatu badan usaha dimana dilakukan pekerjaan administrasi yang dapat dilakukan dengan tangan atau mesin".

Kemudian Moekijat (2002 : 2) menjelaskan pengertian kantor adalah :setiap tempat yang biasanya dipergunakan untuk melaksanakan pekerjaan tatausaha (pekerjaan kantor, pekerjaan tulis menulis).

Begitu juga oleh Ida Nuraida (2008) mengatakan bahwa : "Kantoradalah tempat diselenggarakan kegiatan tata usaha dimana terdapat ketergantungan sistem antara orang, teknologi, dan prosedur untuk menangani data dan informasi mulai dari menerima, mengunpulkan, mengolah menyimpan sampai menyalurkannya".
Kantor adalah keseluruhan ruang yang menjadi tempat melangsungkan kegiatan tata usaha atau kegiatan manajemen atau tugas pimpinan lainnya dalam sebuah organisasi teryata hampir seluruh kantor, besar atau kecil, pada dasarnya memiliki kegiatan rutin dan organisasi yang hampir serupa. Kantor berhubungan dengan manajemen informasi dan perawatan aktiva. Proses informasi dalam kantor itu dapat dikelompokkan ke dalam bagian-bagian berikut.

$>$ Hasil pelaksanaan

$>$ Pemeliharaan catatan oleh sistim akutansi dan arsip

$>$ Komunikasi tulisan atau lisan

$>$ Sisrimatisasi penunman biaya melalui analisa sistim dan anaJisa prosedur.

Untuk apakah kegiatan-kegiatan diatas itu dilakukan keempat kegiatan kegiatan tersebut diperlakukan untuk adanya efisiensi koordinasl, permodalan, distribusi, dan produksi. Melalui titik pusat yang dikenal sebaagai "kantor" itu, koordinasi memberikan kemudahan bagi analisa sejarah untuk pengawasan dipennudah.

Kantor sebagai pusat administrasi dan perencanaan kebijaksanaan adalah menarik kiranya, bahwa kantor sebagai suatu yang berfungsi eksekutif, harus bertindak sebagai pusat syaraf administrasi. Dengan demikian, kantor itu membantu perumusan dalam membuat keputusan mengenai hasil barang apa yang dibuat, kapan membeli bahan, ke daerah mana akan dijual, kemana setiap laporan kegiatan yang akan ditujukan. Pada dasamya, kantor itu menjadi jantungkegiatan usaha dalam memberikan informasi bagi pembelian, penjualan,penyimpanan, aktifitas kegiatan keuangan, dan komunikasi.

Kantor sebagai tempat penyelesaian persoalan dan masalah sehingga dapat diterangkan melalui transaksi berikut ini, jika barang terjual misalnya, sama seperti kegiatan membeli barang, kegiatan dibawah ini dipergunakan ;

$>$ Menerima pesanan melalui surat, telegram atau telepon

$>$ Memperoleh laporan kredit melalui dokumentasi yang ada

$>$ Mensahkan pengiriman barang oleh kantor

$>$ Mempersiapkan, mencatat, dan mengirimkan faktur penjualan

Mendiktekan dan mengirimkan surat 
Mengarsipkan semua catatan ditempat yang benar.

\section{Badan Pusat Stasistik (BPS)}

Badan Pusat Statistik adalah Lembaga Pemerintah Non-Departemen yang bertanggung jawab langsung kepada Presiden. Sebelumnya, BPS merupakan Biro Pusat Statistik, yang dibentuk berdasarkan UU Nomor 6 Tahun1960 tentang Sensus dan UU Nomer 7 Tahun 1960 tentang Stalistik

Sebagaipengganti kedua UU tersebut ditetapkan UU Nomor 16 Tahun 1997 tentang. Statistik. Berdasarkan UU ini yang ditindaklanjuti dengan peraturan perundangan dibawahnya, secara fonnal nama Biro Pusat Statistik diganti menjadi Badan Pusat Statistik.Materi yang merupakan muatan baru dalam UU Nomor 16 Tahun 1997, antara lain:

$>$ Jenis statistik berdasarkan tujuan pemanfaatannya terdiri atas statistik dasar yang sepenuhnya diselenggarakan oleh BPS, statistik sektoral yangdilaksanakan oleh instansi Pemerintah secara mandiri atau bersama dengan BPS, serta statistik khusus yang diselenggarakan oleb lembaga, organisasi, perorangan, dan atau unsur masyarakat lainnya secara mandiri atau bersama dengan BPS.

> Hasil statistik yang diselenggarakan oleh BPS diumumkan dalam BeritaResmi Statistik (BRS) secara teratur dan transparan agar masyarakat dengan mudah mengetahui dan atau mendapatkan data yang diperlukan.

> Sistem Statistik Nasional yang andal, efektif, dan efisien.

$>$ Dibentuknya Forum Masyarakat Statistik sebagai wadah untuk menampung aspirasi masyarakat statistik, yang bertugas memberikan saran dan pertimbangan kepada BPS.

Berdasarkan undang-undang yang telah disebutkan di atas, peranan yangharusdijalankan oleh BPS adalah sebagai berikut :

$>$ Menyediakan kebutuhan data bagi pemerintah dan masyarakat. Data inididapatkan dari sensus atau survey yang dilakukan sendiri dan juga daridepartemen atau lembaga pemerintahan lainnya sebagai data sekunder
Membantu kegiatan statistik di departemen, lembaga pemerintah atau institusi lainnya, dalam membangun sistem perstatistikan nasional.

$>$ Mengembangkan dan mempromosikan standar teknik dan metodologistatistik, danmenyediakan pelayanan pada bidang pendidikan dan pelatihan statistik.

\section{Tugas dan Fungsi Badan Pusat Statistik (BPS)}

a. Tugas

Me1aksanakan tugas pemerintahan di
bidang kegiatan denganketentuan peraturan perundang-undangan yang berlaku,

b. Fungsi

$>$ Penyelenggaraan statistik dasar;

$>$ Koordinasi kegiatan fungsional dalam pelaksanaan tugas BPS;

> Fasilitasi pembinaan terhadap kegiatan instansi pemerintah di bidang kegiatan statistik; Penyelenggaraan pembinaan dan pelayanan administrasi umum di bidang perencanaan umum, ketatausahaan, organisasi clan tatalaksana, kepegawaian, keuangan, kearsipan, hukum, persandian, perlengkapan dan rumah tangga.

\section{Wewenang Badan Pusat Statistik (BPS)}

a. Penyusunan rencana secara makro di bidangnya;

b. Perumusan kebijakan di bidangnya uotuk mendukung pembangunan secaramakro;

c. Penetapan sistem infonnasi di bidangnya;

d. Penetapan dan penyelenggaraan statistik Kabupaten;

e. Kewenangan lain sesuai dengan ketentuan peraturan perundangundanganyang berlaku, yaitu:

$>$ Perumusan dan pelaksanaan kebijakan tertentu di bidang kegiatan statistik;

$>$ Penyusun pedoman penyelenggaraan survei statistik sektoral.

\section{Sistem Informasi Manajemen \\ Perkantoran \\ Untuk meningkatkan daya guna dan basil guna dari pelaksanaan manajemen}


perkantoran perlu dilaksanakan berbagai kegiatan kegiatan kantor berdasarkan suatu system sehingga tujuan yang diinginkan akan mencapaisasaran. Tugas yang dibebankan pada masing-masing bagian harus ada refevansinya supaya tidak terjadi penyalah gunaan atau tumpang tindih dalam pelaksanaan tugas.

1. Jenis-jenis Sistem informasi

Didalam organisasi/perusahaan apapun terdapat sejumlah sistem informasi yang berbeda yang memberikan informasi terus-menerus kepada pemakai pada semua tingkat. Data informasi mengalir naik turun, biasanyadengan laporan lisan atau tulisan, manual atau digital, yang digunakan untuk tindakan kontrol dan koreksi.

Sering kali pegawai merasa lebih senang mencari bantuan atau informasi dari rekan sekerja ketimbang dari supervisor dan interaksi langsung antar pegawai dapat memecahkan masalah yang berhubungan dengan pekerjaan. Sistem ini bertindak sebagai sarana penyebaran informasi secara cepat dan memberikan umpan balik.

2. Pengertian Sistem Informasi Manajemen

Sistem informasi manajemen adalah suatu sistem yang saling bekerja sama yang terdiri atas kumpulan orang, alat, dan prosedur yang merupakan satu kesatuan yang saling berinteraksi dan berkesinambungan yang dirancang untuk mengumpulkan, memilih, menganalisis, mengevaluasi, dan mendistribusikan informasi yang baik dan siap pakai guna menghasilkan perencanaan, implementasi, dan pengendalian manajemen yang baik melalui pembuatan keputusan.

Sistem Informasi Manajemen dlbakukan dalam prosedur kerja kantor. Prosedur kerja memudahkan kegiatan yang repetitif dan rutin sehingga setiapkali terjadi tidak perlu dianggap sebagai hal yang baru yang perlu difikirkanlagi cara penanganannya.

\section{Manfaat Informasi}

Informasi perlu dikelola dengan baik agar kantor dapat mengelola pekerjaan pada masa sekarang dan masa yang akan datang. Efektifitas kantor tidak akan tercapai tanpa planing yang baik, yang merupakan syarat untuk dapat melakukan organizing, actuating, dan contolling dengan baik. Planing, organizing, actuating, dan controling yang baik hanya dapat tercapai denganpengelolaan informasi yang baik pula.

\section{Prosedur Perkantoran}

Prosedur merupakan bagian dari .rencana kantor. Jenis-jenis rencanameliputi misi, tujuan, strategi, kebijaksanaan, prosedur peraturan, progaram dan anggaran, (Komaruddin Sastradipoetra, 1999). Strategi merupakan tujuan dasar jangka panjang yang memberi arah bagi aktifitas perusahaan dan menjadi dasar pengalokasian sumber daya yang dibutuhkan untuk mencapai tujuan. Prosedur terdiri atas rangkaian peraturan yang harus diikuti untuk mencapai tujuan tertentu, akan tetapi peraturan belum tentu merupakan bagian dari prosedur.Prosedur harus mendapatkan perhatian serius dalam manajemen administrasi perkantoran.

Prosedur perkantoran atau system perkantoran adalah urutan atau langkah-langkah melakukan pekerjaan yangberhubungan yang dilakukan, bagaimana melakukannya, bilamana melakukannya, dimana melakukannya, dan siapa yang rnelakukannya (Moekijat, 1997 : 53). Dengan demikian dapat disimpulkan prosedur merupakan metode-metode yang dibutuhkan untuk menangani aktifitas- aktifitas yang akan datang.

1. Manfaat Prosedur

Prosedur sangat bermanfaat bagi level manajerial maupun non- manajerial dalam melaksanakan fungsi manajemen dibagiannya msing- masing diantaranya sebagai berikut :

a. Planning-controlling

$>$ Mempermudah pencapaian tujuan

$>$ Merencanakan dengan seksama tentang besamya beban kerja yang optimal bagi masing-masing pegawai.

$>$ Menghindari pemborosan atau memudahkan penghematan biaya.

b. Organizing

$>$ Dihubungkan dengan alat-alat yang mendukung pekerjaan kantor sertadokumen-dokumen kantor yang diperlukan.

$>$ Mengakibatkan arus pekerjaan kantor menjadi lebih lancar dan baik,serta menciptakan konsistensi kerja.

\section{Staffing-leading}

$>$ Membantu atasan dalam memberikan pelatihan atau dasar-dasar intruksikerja bagi pegawai barn dan pegawai lama. 
> Atasan perlu mengadakan penyuluhan bagi bawahan yang bekerja tidaksesuai dengan prosedur.

$>$ Mempermudah pemberian penilaian terhadap bawahan.

d. Coordination

$>$ Menciptakan koordinasi yang harmonis bagi tiap departemen dan antar departemen .

$>$ Menetapkan dan membedakan prosedur-prosedur yang rutin dan prosedur-prosedur yang independen.

Prosedur kerja ada pada setiap bagian dalam struktur organisasi perusahaan, prosedur kerja yang baik mencermink:an pengelolaan sistem informasi manajemen yang baik yang mempermudah dan menyederhanakan pelaksanaan pekerjaan dan bukan untuk mempersulit, apalagi sampai menghambat pelaksanaan pekerjaan kantor. Secara garis besar, prosedur kerjaharus mendukung pencapaian tujuan secara efesien, mempermudah koordinasi intern dan ekstern, serta membantu terciptanta informasi yang baik dan siap pakai.

\section{PEMBAHASAN}

\section{A. Struktur Organisasi Badan Pusat Statistik (BPS)}

Untuk melaksanakan tugas, fungsi, dan kewenangan tersebut, sesuai Keputusan Kepala Badan Pusat Statistik (BPS) Nomor 121 Tahon 2001 tentang Organisasi dan Tata Kerja Perwakilan Badan Pusat Statistik di Daerah, telah ditentukan struktur organisasi Badan Pusat Statistik (BPS) Kabupaten Pidie,yaitu:

1. Kepala

$\begin{array}{cccc}\text { Kepala } & \text { Badan } & \text { Pusat Slatistik } & \text { (BPS) } \\ \text { Kabupaten } & \text { Pidie } & \text { mempunyai } & \text { tugas }\end{array}$ mengkoordinasikan perencanaan, pembinaan dan pengendalian terhadap program, administrasi dan sumber daya di lingkungan Badan Pusat Statistik (BPS) Kabupaten Pidie. Kepala membawahi Sub Bagian Tata Usaha, Seksi Statistik Sosial, Seksi Statistik Produksi, Seksi Statistik Distribusi, Seksi Neraca Wilayah dan Analisis Statistik, Seksi Integrasi Pengolahan danDiseminasi Statistik, Koordinator Statistik Kecamatan (KSK), Staf danPegawai Fungsional.

2. Sub Bagian Tata Usaba

Sub Bagian Tata Usaha mempunyai tugas melaksanakan program dan administrasi perkantoran sesuai dengan kebijakan pimpinan dan undang- undang yang berlaku.

3. Seksi Statistik Sosial

Seksi Statistik Sosial mempunyai tugas melaksanakan program dan kegiatan statistik di bidang statistik sosial mulai dari tahap persiapan, pelaksanaan, dan evaluasi kcgiatan.

4. Seksi Statistik Produksi

Seksi Stalistik Produksi mempunyai tugas melaksanakan program dan kegiatan statistik di bidang statistik produksi mulai dari tahap persiapan, pelaksanaan, clan evaluasi kegiatan.

5. Seksi Statistik Distribusi

Seksi Statistik Distribusi mempunyai tugas melaksanakan program dankegiatan statistik di bidang statistik distribusi mulai dari tahap persiapan,pelaksanaan, dan evaluasi kegiatan.

6. Seksi Neraca Wilayah dan Analisis Statistik

Seksi Neraca Wilayah dan Analisis Statistik mempunyai tugas melaksanakan program dan kegiatan sraristlk, dan melakukan analisis terhadap data yang diperoleh dari sensus/survei.Seksi Integrasi Pengolahan dan Diseminasi StatistikSeksi Jntegrasi Pengolahan dan Discminasi Statistik meropunyai tugas rnelaksanakan program dan kegiatan statistik, dan melakukan pengolahan data yang di_peroleh dari sensus/survei.

7. Koordinator Statistik Kecamatan (KSK)

Koordinator statistik kecamatan (KSK) mempunyai tugas mengkoordinasikan dan melaksanakan program dan kegiatan statistik di kecamatan masing-masing.

\section{B. Proses Manajemen Perkantoran Badan Pusat Statistik (BPS) Kabupaten Pidie}

Selain dari beberapa pennasalahan yang telah dikemukakan diatas, maka disini akan dikemukakan proses manajemen perkantoran Badan Pusat Statistik(BPS) Kabupaten Pidie, bahwa susunan organisasi Badan Pusat Statistik (BPS)Kabupaten Pidie terdiri dari Kepala, Sub Bagian Tata Usaha, Seksi StatistikSosial, Seksi Statistik Distribusi, Seksi Neraca Wilayah dan Analisis Statistik,Seksi Integrasi Pengolahan dan Diseminasi Statistik, dan Koordinator StatistikKecamatan (KSK).

Disamping tugas-tugas yang dilaksakan oleh Sub Tata Usaha sebagaimana yang telah disebutkan diatas, maka Sub Tata Usaha juga melaksanakan fungsi-fungsi seperti :

1. Menyusun rencana dan program kerja, 
2. Menyusun anggaran dan pengelolaan keuangan,

3. Melaksanakan administrasi dan tatausaha,

4. Mengelola kepegawaian, dan perlengkapan kantor,

5. Mengkoordinasikan pelaksanaan tugas dengans seksi-seksi lainnya,

6. Melaksanakan evaluasi dan pclaporan program kantor,

7. Melaksanakan tugas-tugas Jain yang diberikan oleh Kepala Kantor.

a. Pengurusan Surat Masuk dan Surat Keluar

Sub Tata Usaha Badan Pusat Statistik (BPS) Kabupaten Pidie juga melaksanakan alat menangani berbagai kegiatan lainnya seperti surat masuk dan surat keluar. Surat masuk adalah surat yang masuk kedalam suatu instansi/ perusahaan atau bagian dalam suatu instansi/perusahaan yang berasalbaik dari instansi/perusahaan lain atau dari bagian lain di instansi/perusahaanyang sama. Sedangkan surat keluar adalah surat yang dikirim oleh suatu instansi/perusahaan at.au dari bagian di dalam instansi/perusahaan tersebut yang ditunjukan ke instansi/perusahaan lain atau kebagian lain dalam instansi/perusahaan yang sama.

Adapun jenis surat masuk yang ditangani oleh Sub Tata Usaha seperti Surat Kegiatan Kehumasan dan Kampanye ST 2013, Surat Pembuatan Daftar DP3 Tahun 2013, Surat PeJaksanaan Peresmian Gedung Kantor dan lain-lain. Sedangkan jenis surat keluar adalah Surat Pembukaan Cek Biro Kantor danPembuatan Buku Cek, Surat Pengantar Rekom K.PKNL dan lain-lainnya.

b. Laporan/Dokumen Kantor

Pencacatan dokumen kantor

bermacam-macam kegunaanya. Salah satunya adalah pencatatan untuk menelusuri arsip yang bertujuan agar arsip dapat ditemukan kembali dengan mudah dan cepat. Pengarsipan dan pencacatan dokumen untuk menelusuri arsip tidak dapat dipisahkan satu sama lain karena saling berkaitan dan memengaruhi. Hal ini disebabkan sebagai berikut :

a. Pengarsipan tanpa pencacatan dokumen dapat menyebabkan inesifiensi daninefektifit.as. Hal ini akan menyita waktu, tenaga dan biaya untuk mencari arsip yang diperlukan. Semakin banyak arsip perusahaan, sernakin sulit ditemukan jika tidak ada pcncacatannya. Maka pegawai arsip membutuhkan waktu lama untuk mencari arsip yang dibutuhkan, dengan memeriksa tempat penyimpanan arsip. Hal ini akan menundadan bahkan menghambat pengambilan keputusan yang berkualitas.

b. Apabila kegiatan pencacatan dokumen tidak berkoordinasi dengan kegiatan pengarsipan, akan menyulitkan tindakan pengawasan dan pengendalian terhadep arsip-arsip yang disimpan disemua tempat penyimpanan arsip, yaitu tidak dapat diketahui secara pasti apakah arsip yang pernah disimpan masih ada atau sudah tidak ada lagi ditempat penyimpanannya,atau terjadi ketidakcocokan antara arsip dicatatan dengan dilemari arsip tidak cocok atau arsip tercatat tidak ditemukan ditempatnya.

Semua laporan ini harus dikirim oleh Sub Tata Usaha Badan PusatStatistik (BPS) Kabupaten Pidie tiap bulan, paling lambat tanggal 10 sudahterkirim kc lnspektorat utama, dan paling lambat tanggal 15 sudah terkirim keSekretariat Utama BPS RI.

\section{Arsip}

Arsip sebagai kumpulan surat yang mengandung arti dan mempunyai nilai guna, baik untuk kepentingan organisasi maupun kepentingan pribadi yang disimpan sebegitu rupa sehingga apabila sewaktu-waktu dipergunakan dapat ditemukan kembaii dengan mudah dan cepat, jadi sistem penyimpanan arsip Badan Pusat Statistik (BPS) Kabupaten Pidie, khususnya pada SubKetata Usahaan dapat dikatakan belum terlaksana sebagaimana ketentuanyang ditetapkan sehingga tidak dapat meningk:atkan efesiensi dan efektifitas kerja pegawai dari segi waktu maupun tenaga yang dibutuhkan.Setiap perusahaan pasti memiliki arsip.

Pada praktiknya penyimpanan data dan informasi dalam bentuk sistem arsip seringkali tidak diperhatikan, tidak diminati, atau dianggap tidak penting untuk dipahami dan diterapkan dikantor sehingga tidak dibuat perencanaan dan pengendalian arsip yang baik. Padahal fungsinya sangat peoting bagi kelancaran operasi, sebagai bahan untuk pengambilan keputusan bisnis dan lain-lain 
karena infonnasi untuk membuat keputusan baru dicari di arsip.

\section{Keadaan Sarans dan Prasarana}

Sarana dan prasarana merupakan perlengkapan kantor yang sangat penting untuk mendukung pelaksanaan manajemen perkantoran Badan Pusat Statistik (BPS) Kabupateo Pidie. Kelengkapan sarana dan prasarana akan mempermudah pelaksanaan tugas dan memberikan kegairahan kerja bagi pegawai ditambah lagi dengan kemampuan pegawai yang sudah memadai sehingga pelaksanaan tugas dapat dilaksanakan sebagaimana mestinya.Berikut data prasarana dan sarana Badan Pusat Statistik (BPS) KabupatenPidie yang dimiliki saat ini adalah sebagai berikut:

TABEL I-1

JUMLAH SARANA DAN PRASARANA BADAN PUSATSTATISTIK (BPS) KABUPATEN PIDIE 2018

\begin{tabular}{|c|l|c|c|}
\hline No & \multicolumn{1}{|c|}{$\begin{array}{c}\text { Sarana/ } \\
\text { Prasarana }\end{array}$} & $\begin{array}{c}\text { Jumlah } \\
\text { (Unit) }\end{array}$ & Keterangan \\
\hline 1 & Meja Biro & 8 & Baik \\
\hline 2 & Meja 1/2 biro & 4 & Baik \\
\hline 3 & Kursi putar & 20 & Baik \\
\hline 4 & Kursi biasa & 5 & Baik \\
\hline 5 & Lemari 3 pintu & 5 & Baik \\
\hline 6 & Lemari 2 pintu & 4 & Baik \\
\hline 7 & Filling cabinet & 5 & Baik \\
\hline 8 & Meja/ kursi tamu & 2 & Baik \\
\hline 9 & Rak besi & 1 & Baik \\
\hline 10 & Rak kayu & 1 & Baik \\
\hline 11 & Kamera CCTV & 1 & Baik \\
\hline 12 & Laptop & 10 & Baik \\
\hline & Jumlah & 77 & Baik \\
\hline
\end{tabular}

Sumber data : Badan Pusat Statistik (BPS) Kabupaten Pidie, diolah Juli 2018.

Berdasarkan Data table I- 1 diatas, menunjukan bahwa sarana dan prasarana kantor yang dimiliki Badan Pusat Statistik Kabupaten Pidie dalam kondisi baik walaupun relative terbatas.Sarana dan prasarana sebagai alat penunjang utama dalam pelaksanaan proses manajemen perkantorao sesuai dengan kebutuhan kantor yang bersangkutan, Secara umum Badan Pusat Statistik (BPS) Kabupaten Pidie, mernpunyai sarana dan p.rasarana perlengkapan kantor menurut kebutuhan meskipun semua sarana dan prasarana tersebut belum sepenuhnya memadai.

5. Pengurusan Keuangan

Faktor keuangan merupakan salah satu faktor yang sangat menentukan dalam setiap kegiatan pada sebuah organisasi, Apabila faktor keuangan telah memadai, maka semua pelaksanaan kegiatan kantor ak:an terlaksanasebagaimana yang diharapkan. Sebaliknya jika faktor dana kurang memadai,maka setiap kegiatan yang dilakukan kurang mencapai hasil yang maksimal.

6. Keadaan Pengawai

Pengawai Negeri Sipil merupakan orang yang menjalankan berbagai macam tugas pada Sadan Pusat Sratistik (BPS) perlu ditata dan dibina sehingga mampu dalam menjalankan tugas yang telah di bebankan kepadanya,Pernbinaan yang di lakukan dapat berupa memberikan berbagai latihanjabatan dan keterampilan sesuai dengan kemampuan dari Pengawai Negeri Sipil yang bersangkutan. Jumlah dan mutu pengawai sangat mendukung produktifitas kerja, sehingga hasil dicapai sesui dengan yang diinginkan.

Pengawai badan pusat statistik (BPS) kabupaten pidie lebih dominan pegawai lakilaki. Dalam rangka peningkatan kinerja para pegawai dalam melayani masyarakat, sangat di perlukan pendidikan yang memadai sehingga dapat memberi kepuasan maksimal.

7. Pengadaan Pegawai

Formasi Pegawai Negeri Sipil merupakan jumlah dan susuoan pangkat Pegawai Negeri Sipil yang diperlukan dalam suatu organisasi pemerintah agar mampu melaksanakan tugas pokok dalam jangka waktu tertentu. Pengadaan Pegawai Negeri Sipil merupakan suatu formasi yang lowong dan mendapatkan Pegawai Negeri Sipil yang profesional, berkualitas serta dapat mewujudkan objektivitas dalam pegadaan Pegawai Negeri Sipil.

Pengadaan Pegawai Negeri Sipil dilakukan dari perencanaan, pengumuman, pelamaran, penyaringan, pengangkatan Calon Pegawai Negeri Sipil sampai dengan pengangkatan menjadi Pegawai Negeri Sipil.

Berdasarkan kenyataan yang ditemui dari hasilpenelitianmenunjukkan bahwa 
formasi Pegawai Negeri Sipil Badan Pusat Statistik(BPS) Kabupaten Pidie telah di susun sesuai menurut pangkat yang diperlukandan telah dilaksanakan sesuai dengan ketentuan dan peraturan perundang- undangan yang berlaku.

Menyangkut dengan pengadaan Pegawai Negeri Sipil berdasarkan kenyataan yang ditemui, hasil penelitian bahwa selama 2 tahun terakhir Badan Pusat Statistik (BPS) Kabupaten Pidie tidak diadakan pengadaan pegawai baru, walaupun formasi yang ada belum penuh.

8. Pengawasan

Pengawasan adalah proses kegiatan yang dilakukan untuk mengamati apakah pelaksanaan pekerjaan yang telah dilaksanakan dan dilakukan sesuai dengan rencana yang telah ditetapkan sebelumnya. Maka dengan demikian pengawasan mempunyai hubungan yang erat dengan rencana.Hal inl berarti bahwa tanpa rencana pengawasan tidak dapat dilaksanakan, oleh karena tidak ada pedoman untuk melaksanakan pengawasan.

Tujuan dari pada pengawasan adalah untuk mengetahui apakahsesuatu pekerjaan berjalan sesuai dengan yang diharapkan atau direncanakan atau pun pengawasan adalah sesuatu yang dilaksanakan sesuai dengan intruksi serta azas-azas yang telah ditentukan dan untuk mengetahui segala sesuatu berjalan dengan efektif dan efesien, jika ternyata dijumpai kesulitan dankelemahan atau pun kegagalan bisa langsung dilakukan perbaikan.

\section{Hambatan-Hambatan Yang Ditermui}

Didalam menjalankan organisasi baik organisasi pemerintah maupun organisasi swasta tidak terlepas dari berbagai faktor yang menjadi hambatan atau kendala, baik harnbatan itu datang dari luar organisasi maupun dari dalam organisasi. Adakalanya hambatan yang disebabkan sumber daya manusia yangkurang profesional dalam menjalankan tugasnya, juga bisa sumbersumber lain yang kurang memadai seperti dana dan prasarana yang dimiliki oleh masing- masing organisasi tersebut. Begitu pula halnya dalam proses manajemen perkantoran Badan Pusat Statistik (BPS) Kabupaten Pidie, juga ditemui beberapa faktor penghambat sebiogga pelaksanaan tugas-tugas tersebut belum terlaksana sebagaimana mestinya.
Adapun hambatan-hambatan yang dimaksud antara lain adalah :

a. Terbatasnya kemampuan para pegawai dalam menata manajemenperkantoran,

b. Terbatasnya saranadan prasarana yang dimiliki oleh Badan Pusat Statistik(BPS) Kabupaten Pidie.

\section{Upaya-Upaya yang Dapat Ditempuh}

Untuk menanggulagi berbagai hambatan atau upaya yang perlu dilakukan terhadap permasalahan timbul dalam proses manajemen perkantoran Badan Pusat Statistik (BPS) Kabupaten Pidie, perlu ditempuh beberapa upaya antara lain adalah sebagai berikut:

1. Kepada setiap pegawai Badan Pusat Statistik (BPS) Kabupaten Pidie perlu diberikan berbagai latihan atau kursus-kursus dalam bidang manajemenperkantoran guna meningkatkan prestasi kerja.

2. Untuk kelancaran pelaksanaan tugas, maka perlu dilengkapi sarana danprasarana yang masih kurang sehingga pelaksanaan tugas dapat dilaksanakansebagaimana yang diharapkan.

Sebagaimana yang telah dikemukakan dalam basil penelitian yang menunjukkan bahwa, sangat berat dan kompleknya tugas yang harus dilaksanakan oleh pegawai pada Badan Pusat Statistik (BPS) Kabupaten Pidie. Disamping harus menata manajemen dilingkungan kantor, juga harus melaksanakan tugas pemerintahan dibidang kegiatan statistik sesuai dengan ketentuan peraturan perundang-undangan yang berlaku.

Maka dalam proses manajemen perkantoran khususnya yangdilaksanakan dibawah Sub Tata Usaha yang menyusun rencana dan program kerja, menyusun anggaran dan pengelolaan keuangan, melaksanakan administrasi dan tatausaha, mengelola kepegawaian, perlengkapan kantor dan lain-lainya.

Semua tugas-tugas perlu dilakukan secara efektif dan efesien berdasarkan ketentuan-ketentuan yang telah ditetapkan sebelumnya, jadi pegawai merupakan unsur penyelenggara dari tugas-tugas yang dibebankan padanya untuk dapat berjalan sebagaimana yang diharapkan. Mengurus tata 
persuratan baik yang menyangkut dengan surat masuk dan surat ke1uar maupun juga 1aporan dokumen merupakan salah satu tugas yang harus dilaksanakan oleh Sub Tata Usaha Badan Pusat (BPS) Statistik Kabupaten Pidie.Surat merupakan salah satu alat komunikasi tertulis yang berasal dari satu pihak dan ditujukan dari pihak lain untuk menyampaikan berita dengan demikian jelas bahwa surat sangat penting artinya dalam membantu memperlancar tercapainya tujuan organisasi. Maka surat menyurat sangatlah penting dalam suatu organisasi karena suratmenyurat merupakan salah satu bagian dari proses komunikasi dalam organisasi yang berbentuk tulisan, proses surat menyurat ini lebih diutamakan untuk lingkungan ekstem organisasi yang sangat berpengaruhdalam menciptakan link organisasi.

Maka perlu diusahakan agar Sub Tata Usaha Badan Pusat Statistik (BPS) Kabupaten Pidie dapat membuat surat maupun laporan dokumen dengan baik, sebab penilaian negatif terhadap surat dan laporan dokumen akan dapat mempengaruhi pula penilaian negatif dalam organisasi. Dengan adanya surat maupun laporan dokumen yang baik dan rapi, maka dapat mendukung tercapainya tujuan organisasi yaitu bisa benahan dan bisa tumbuh berkembang.

Kecakapan seorang pegawai sangat menunjang terhadap proses manajemen perkantoran pada sebuah organisasi, karena tanpa adanya pegawai yang terampil maka tidak mungkin dapat menunjang aktivitas kerja dan tidak dapat juga meningkatkan kemampuan kerja sehingga perlu pembinaan terhadap pegawai secara terus menerus.Dalam hal pembinaan terhadap pegawai Badan Pusat Statistik (BPS) Kabupaten Pidie, perlu mengambil langkah-langkahdengan mengadakan pelatihan dan kursus, ini dilakukan dengan tujuan untuk meningkatkan ketrampilan dan kemampuan pegawai dalam menata proses manajemen perkantoran, disamping itu pimpinan juga harus memberikan kesempatan kepada pegawai untuk melanjutkan pendidikan atau latihan untuk kursus-kursus yang diselenggarakan ditingkat Kabupaten maupun ditingkat propinsi karena perlu dilakukan guna untuk meningkatkan kemampuan dan semngat kerja dalam menjalankan proses manaajemen perkantoran.

Dalam pembinaan sumber daya manusia/pegawai Negeri Sipil dilingkungan
Badan Pusat Statistik (BPS) Kabupaten Pidie, banyak bidang yang perlu dilakukan pelatihan, sehingga pegawai yang bersangkutan benarbenar terampil dan mampu menjalankan berbagai tugas yang telah dibebankan kepadanya.Didalam organisasi yang besar, makaseseorang administrator dalammenjalankan tugasnya harus di bantu oleh orang lain supaya seluruh kegiatanorganisasi berjalan dengan baik dan lancar. Manajemen adalah suatu proses yangterdiri dari tindakantindakan yang dimulai dari penentuan tujuan sampaipengawasan, dimana masingmasing bidang digunakan baik ilmu pegetahuan maupun keahlian yang diikuti secara berurutan dalam rangka usaha mencapai sasaran yang telah ditetapkan semula. Dengan diterapkan manajemen yang baik, maka diharapkan seorang pegawai mempunyai keterampilan dan propesional dalam menjalankan tugasnya.

Bahwa Manajemen/Pembinaan Pegawai Negeri SipiJ belum sepenuhnya dapat dilaksanakan Badan Pusat Statisrik (BPS) Kabupaten Pidie, disamping itu pembinaan yang dilakukan oleh pimpinan juga relative kurang, hal ini didapati hanya sebagian dari pegawai Badan Pusat Statistik (BPS) Kabupaten Pidie yang telah mengikuti latihan jabatan, dan juga sebagian yang kurang disiplin dalam melaksanakan tugasnya.

Kenyataan yang ditemui Badan Pusat Statistik (BPS) Kabupaten Pidie bahwa masih ada formasi yang belum terisi, dan selama dua tahun terakhir Badan Pusat Statistik (BPS) Kabupaten Pidie juga tidak diadakan penerimaan pegawai barn.Untuk sarana dan prasarana yang dimiliki Badan Pusat Statistik (BPS) Kabupaten Pidie masih terbatas dan perlunya penambahan supaya efektif dalam pelaksanaan proses manajemeit perkantoran.

Dalam hal peralatan kantor penulis ingin mengemukakan tentang pennasalahan yang menyangkut tentang pelaksanaan proses manajemen tentang hal-hal yang berkenaan dengan peralatan tersebut, seperti yang telah dikernukakan sebelumnya, peralatan atau sarana yang dimiliki oleh Badan Pusat Statistik (BPS) Kabupaten Pidie jumlahnya sangat terbatas maka dengandemikian dalam hal pelaksanaan tugas sehari-hari dapat menimbulkan hambatan seperti dalam pembuatan laporan maupun surat-surat lainnya. Berdasarkan kenyataandalarn pelaksanaan pekerjaan seharusnya telahdapat 
diJaksanakan tepat waktu namun mengalami hambatan disebabkanterbatasnya sarana yang ada seperti laptop, hal ini jelas akan menghambat terwujudnya efesiensi kerja pegawai terutama ditinjau dari efesiensi waktu, dimana pegawai tersebut telah membuang-buang waktu dengan sia-sia karena menunggu pegawai lain selesai berkerja. Dengan demikian dapat dikatakan perlu adanya keseimbangan sarana dan prasarana agar mendukung terlaksananya efesiensi kerja pegawai.

Dari hasil penelitian bahwa dalam hal penyimpanan arsip Badan PusatStatistik (BPS) Kabupaten Pidie sistem penyimpanannya perlu disempumakan, demikian pula halnya dengan tenaga yang mengelola arsip tersebut juga perludibina dan diberikan keterampilan atau pendidikan khusus dibidang penataan arsiparsip kantor, hal ini bertujuan untuk menghindari terjadinya pemborosan dalam hal memanfatkan waktu dan tenaga, apabila sewaktu-waktu arsip-arsip tersebut dibutuhkan kembali untuk bebagai keperluan.

Kecakapan seorang pegawai sangat menunjang terhadap prosesmanajemen perkantoran pada sebuah organisasi, karena tanpa adanya pegawai yang terampil maka tidak mungkin dapat menunjang aktivitas kerja dan tidak dapat juga meningkatkan kemampuan kerja sehingga perlu pembinaan terhadap pegawai secara terus menerus.

Dalam hal pembinaan terhadap pegawai Badan Pusat Statistik (BPS)Kabupaten Pidie, perlu mengambil langkah-Jangkah dengan mengadakan pelatihan dan kursus, ini dilakukan dengan tujuan untuk meningkatkan keterampilan dan kemampuan pegawai dalam penata proses manajemen perkantoran, disamping itu pimpinan juga harus memberikan kesempatan kepada pegawai untuk melanjutkan pendidikan atau latihan untuk kursus-kursusyang diselenggarakan ditingkat Kabupaten maupun ditingkat propinsi karena perlu dilakukan guna untuk meningkalkan kemampuan dan semngat kerja dalam menjalankan proses manajemen perkantoran.

Pengawasan merupakan hal yang perlu dilaksanakan secara teratur terhadap bawahan agar pegawai dapat melaksanakan tugasnya dengan baik sesuai dengan apa yang telah digariskan. Berdasarkan kenyataan yang diperoleh menunjukan bahwa pengawasan terhadap bawahan sering dilakukan oleh aparatatau bagian yang dibentuk daJam organisasi, selain dari pada itu juga dilak:ukan pengawasan melekat. Setiap atasan berhak mengawasi bawahanya dalam melakukan tugas sehari-hari.

\section{PENUTUP}

\section{Kesimpulan}

1. Proses manajemen perkantoran Badan Pusat Statistik (BPS) Kabupaten Pidie, relatif belum terlaksana sebagaimana mestinya, dikarenakan ditemui beberapa faktor yang menjadi hambatan dalam pelaksanaannya.

2. Hambatan-hambatan yang ditemui antara lain adalah terbatasnya kemampuanpersonil dalam menata manajemen perkantoran antara lain lemahnya motifasi kerja, serta disiplin para pegawai relative sangat rendah dan masih terbatasnya sarana dan prasarana yang dimiliki.

\section{Saran}

1. Disarankan supaya pimpinan Badan Pusat Statistik (BPS) Kabupaten Pidie dapat meningk:atkan pembinaan bawahan dengan memberikan berbagai pendidikan pelatihan dalam bidang manajemen dan administrasi perkantoran.

2. Disarankan supaya sarana dan prasarana yang rnasih kurang pada Badan PusatStatistik (BPS) Kabupaten Pidie hendaknya perlu ditambah lagi sesuai dengan kebutuban kantor, agar da1am pelaksanaan kegiatan kantor dapat teratasi

\section{DAFTAR PUSTAKA}

Irra Crhisyanti Dewi, Manajemen Produkst, Edisi Empat, Penerbit BPEE, Yogyakarta, 2000.

Ida Nuraida, Manajemen Administrasi Perkantoran, Ghalia Indonesia. Yogyakarta,2008.

Kornaruddin Sastradipoetra, Asas-asas Manajemen Perkantoran. Bandung : KappaSigma, 1999.

Kartono, Metode Penelitian. PT. Raja Grafmdo Persada, Jakarta, 1997. 
M. Manulang, ft-fanajemen Kepegawaian di Indonesia, CV. H. Mas Agung Jakarta,2004.

Moekijat, Administrasl Perkanloran, CV. Mandar Maju, Bandung, 2008.

Prajudi Atmosudirjo, HukumAdministrasl Negara, GhaHa Indonesia, Jakarta, 2001.

Panji Anaroga, Psikologl Kerja, PT. Bumi Askara. Jakarta, 2000.

Sukoco, Manejemen Administrasl Modern, Erlangga, 2007. Sindoro, Munajemen Strategis, PT Prehalindo, Jakarta, 2004.

Sarwoto, Dasar-dasar Organisasi dan Manajemen, Ghalia Indonesia, Jakarta, 2000.

Sondang P. Siagian, Peranan Sta/Da/am .Manajemen, Liberty, Yogyakarta, 2002. The Liang Gie, Administrasi Perkantoran Modern, CV. H. Mas Agung Jakarta,2001.
Winardi, ftfotivasi dan Pemotivasian Manajemen, Nova.Jakarta, 2002. 